DOI: 10.38136/jgon.791755

\title{
Doğum eyleminde ebelerle iletişimin doğum deneyimine etkisi
}

\section{The effect of communication in the childbearing process on women's birth experience}

\author{
Tuğba KAYA \\ Selda ILDAN ÇALIM ${ }^{2}$ \\ Gülten UÇAN ${ }^{3}$
}

(1) Orcid ID:0000-0001-8725-9127

(1) Orcid ID:0000-0001-8500-4251

(1) Orcid ID:0000-0002-2920-1979

\author{
${ }^{1}$ Serbest Ebe \\ ${ }^{2}$ Manisa Celal Bayar Üniversitesi Sağlık Bilimleri Fakültesi Ebelik Bölümü, Yunusemre, Manisa \\ ${ }^{3}$ Manisa Celal Bayar Üniversitesi Sağlık Bilimleri Fakültesi Sosyal Hizmetler Bölümü, Yunusemre, Manis
}

\section{Öz}

Amaç: Doğum sürecinde ebelerle iletişiminin kadınların doğum deneyimine etkisini incelemektir.

Gereçler ve Yöntemler: Bu tanımlayıcı tipte kesitsel araştımanın örneklemini, Mart 2016- Ekim 2016 tarihleri arasında İzmir'de Sağlık Bakanlığı'na bağlı bir devlet hastanesinde normal doğum yapmış 353 kadın oluşturmaktadır. Katılımcılarla yapılan yüzyüze görüşmelerde veri toplamak için "Lohusa Tanıtım Formu", "Doğumda Ebeyle İletişimi Değerlendirme Formu" ve "Wijma Doğum Beklentisi/Deneyimi Ölçeğinin B Versiyonu" kullanılmıştır. Bulguların analizinde SPSS istatistik programı aracilığıyla frekans, yüzde, ortalama, standart sapma hesaplanmış, ki kare ve korelasyon analizleri uygulanmıştı.

Bulgular: Katılımcıların yaş ortalaması $26,72 \pm 5,05$ olup ortalama doğum sayıs $2,08 \pm 1,07$ 'dir. Doğumların büyük çoğunluğu $(\% 88,7)$ gebeyi takip eden ebe tarafından, \%11,3'ü ise doğum sürecinde müdahale eden ebe ve doktor tarafından yaptırımıştır. Katılımcıların, Doğumda Ebeyle İletişimi Değerlendirme Formu'ndan aldıkları puanların ortalaması 25,03 $\pm 6,52$; Wijma Doğum Beklentisi/Deneyimi Ölçeği'nin B Versiyonu'ndan aldıkları puan ortalaması ise $89,95 \pm 23,08$ 'dir. Bulgular, kadınların ebelerin iletişim davranışlarını algılama düzeyi ile doğum beklentisi/ deneyimi arasında negatif yönlü, orta düzeyde güçlü ve istatistiksel olarak anlamlı bir ilişki olduğunu göstermektedir ( $r=, 36 ; p<0,05)$.

Sonuç: Ebelerin doğum eyleminde sergiledikleri olumlu ve etkili iletişim becerileri, kadınların doğum deneyimini olumlu yönde etkilemiştir.

Anahtar Kelimeler: Ebe, İletişim, Doğum Deneyimi.

\begin{abstract}
Aim: The aim of this study is to examine the relationship between the ability to communicate of midwives with the birth experience of women.

Materials and Methods: The sample of this cross-sectional descriptive research consists of 353 women who gave birth by vaginal delivery in a state hospital affiliated to the Health Ministry in Izmir between March 2016 and October 2016. In order to collect data in face-to-face interviews with the participants, "Puerperant Description Form", "The Communication with Midwife Assessment Form in Childbirth" and "Wijma Scale, B Version of Expectation of Giving Birth /Experience" were used. In the analysis of the findings, frequency, percentage, mean, standard deviation were calculated, chi-square and correlation analysis were applied using the SPSS statistical program.
\end{abstract}

Results: Average age of the women participated to the research is $26,72 \pm 5,05$. Most of the births $(88,7 \%)$ of women were done by the midwife who followed the pregnancy, and $11,3 \%$ of them by midwife and doctor who intervened during the birth process. Average point of the women who have got from Form of Assessment of Communication Perception of Women in the Childbearing Process was found as $25,03 \pm 6,52$ ( $\max : 33,00$ ). The average score obtained by the participants from the Form for the Assessment of Perception of Communication with Midwives in Birth Process is $25.03 \pm 6.52$ (Max: 33.00; The average score they got from Version B of the Wijma Birth Expectancy / Experience Scale is $89.95 \pm$ 23.08. The findings show that there is a negative, moderately strong and statistically significant relationship between women's perception of the communication behaviors of midwives and their birth expectation / experience $(r=, 36 ; p<0.05)$.

Conclusion: The positive and effective communication skills that midwives exhibit during labor positively affect the birth experience of women.

Keywords: Midwife, Communication, Birth Experience 


\section{GiRiş}

Doğum, kadın yaşamının unutulmayan ve etkileri ömür boyu süren deneyimlerinden biridir. Anne ve bebek sağlığı ile doğrudan ilişkili bu benzersiz deneyim sürecini, doğum eylemi süresince yaşadığı stres, yararlandığı bakım hizmeti ve kadının kişilik özelliklerinin etkilediği görülmektedir (1-5). Doğum sürecinde gebe bakımının kalitesini belirleyen önemli bileşenler arasında, sağlık personelinden alınan destek ve kurulan iletişim bulunmaktadır (2,6-8). Ebeler doğum sürecinde kadınlara bakım veren ve iletişim kurdukları en yakın sağlık çalışanlarıdır. $\mathrm{Bu}$ nedenle ebelerin kişilerarası iletişim becerileri, kadınların doğum deneyimlerini olumlu ya da olumsuz yönde etkileyen unsurlar arasında sayılmaktadır $(1,9,10)$. Dahlberg ve Aune (2013), doğum sürecinde olumlu iletişim kurma becerisine sahip ebelerden bakım alan kadınların, psikolojik açıdan kendilerini güvende hissettiklerini ve doğum deneyimlerini olumlu anımsadıklarını belirlemiştir. Ebelerin etkili iletişim kurma becerisine sahip olmaları, gebelere verdikleri sözlü ve sözsüz mesajların doğru algılanmasını sağlayarak bakım vermeyi kolaylaştırmaktadır $(6,11,12)$. Aynı zamanda gebelerin doğum korkusunu ve stresini, doğum ağrısı algısını, doğumda analjezi ve anestezi intiyacını da azaltmaktadır $(1,2,13)$. Etkili iletişim teknikleriyle duygusal olarak desteklenen kadınların, doğum eyleminde ve sonrasında özgüven ve memnuniyet düzeylerinin arttığı görülmektedir. Doğumda verilen bakım hizmetinin kalitesi ve hizmet sağlayan ebelerin iletişim becerileri, kadınların doğumu olumlu deneyimlenmesi için anahtar öğelerdir (6).

Ebelerin mesleki sorumluluklarını yerine getirebilmeleri açısından kişilerarası iletişim becerileri hayati önem taşımaktadır $(6,10-12,14)$. Bakım ve destek hizmetlerinde ebelerin sahip olması beklenen bazı iletişim becerileri ve davranışlar şu şekilde sıralanabilir: Kendini tanıtma, kadını tanımaya çalışma, göz teması kurarak yüz yüze konuşma, etkin dinleme, empati kurma, tutarlı, güven verici, saygılı bir yaklaşım içinde soru sorulmasına ve konuşulmasına fırsat verme, geri bildirimde bulunma, kadını ve ihtiyaçlarını değerli görme, kadının kötü hissetmesine neden olacak söz ve davranışlardan (alay etme, küçümseme, azarlama, tehdit etme, yargılama, hesap sorma, klişe sözlerle yaklaşım) kaçınma $(9,11,12,14,15)$. Ebelerin, kişilerarası iletişim sürecinde etkili olan teknikleri bilme ve kullanma becerilerinin dışında, iyilik, şefkat, merhamet, nezaket gibi vasıflara da sahip olması beklenmektedir $(1,11,12,14,16)$. Dağlar ve Güler'in çalışmasına (2004) katılan kadınların tamamı doğumda kendilerine saygılı davranılmasını istediklerini, sözlerinin dinlenmesini, sorularına cevap verilmesini beklediklerini ifade etmişlerdir. Aynı çalışmada kadınların çoğunluğu kendilerine isimleri ile hitap edilmesi, davranışları ile ilgili geri bildirimde bulunulması, cesaretlendirilme ve fiziksel temas intiyaçlarından bahsetmişlerdir. Sonuç olarak çalışmaya katılan kadınların tamamına yakınının doğumda ebelerden duygusal destek bekledikleri belirlenmiştir (15). Kadınların duygusal hassasiyetinin yüksek olduğu bu dönemde ebelerin kadınlarla iletişim kurarken dikkat etmesi gereken konuları bilmesinin ve pozitif iletişim becerilerine sahip olmasının olumlu doğum deneyimi açısından önemli olduğu görülmektedir (11). Doğum eylemi, kadın ve ailesi için yeni bir bireyin aileye katılacağı duygusal, özel ve unutulmaya- cak bir anıdır. Bu bağlamda araştırmanın amacı, ebelerin iletişim becerilerinin gebelerin doğum deneyimleri üzerine etkisini incelemektir.

\section{GEREÇ VE YÖNTEMLER}

Tanımlayıcı tipteki bu araştırma, Mart 2016 -Ekim 2016 tarihleri arasında İzmir Buca Kadın Doğum ve Çocuk Hastalıkları Hastanesi'nde yürütülmüştür. Araştırmanın örneklemi, araştırmaya dahil edilme kriterlerine (18 yaşından büyük, obstetrik riskleri ve kronik hastalık öyküsü olmayan, doğumun eylemi spontan başlayan, sağlıklı yeni doğana sahip ve doğum eylemi süresince aynı ebe tarafından takibi yapılan) uyan, çalışmaya katılmayı kabul eden kadınlardan oluşmuştur. Araştırmanın örneklem büyüklüğü Openepi programılla \%95 güven aralığında, $\% 50$ bilinmeyen prevelans, $\% 5$ yanılma payı ile ulaşılması gereken en küçük örneklem sayısı n:352 olarak bulunmuştur. Veriler, normal doğum yapmış kadınlarla taburculuk öncesi yüz yüze görüşülerek toplanmıştır.

Araştırmanın veri toplama araçları Lohusa Tanıtım Formu (LTF), Doğumda Ebeyle İletişimi Değerlendirme Formu (DEIDF) ve Wijma Doğum Deneyimi / Beklentisi Ölçeği'nin (WDEQ) B Versiyonu'dur (WDEQ-B). LTF, araştırmacılar tarafından hazırlanmış olup kadınların sosyo-demografik ve obstetrik özelliklerini içeren sorulardan oluşmaktadır.

DEIDF, İldan Çalım'ın "Travelbee Kuramına Göre Verilen Kişilerarası Illetişim Eğitiminin Ebelerin İletişim Becerilerine ve Annelerin Doğum Memnuniyetine Etkisi"(11) konulu çalışmasında Joyce Travelbee'nin kişilerarası iletişim kuramına dayanılarak hazırlanmış ve ebelerin kişilerarası iletişim becerilerini gözlemek amacıyla kullanıımışır. DEIDF maddeleri, kadınların doğumda ebelerle olan iletişim algılarını değerlendirmek amacıyla araştırmacılar tarafından gözden geçirilmiş, uzman görüşleri alınarak yeniden düzenlenmiştir. Bu formda, kadınların doğum eylemi sürecince bakım aldıkları ebelerin iletişim becerileri ile ilgili ifadeler yer almaktadır. Katılımcıların yanıtları subjektif, algılanan iletişimi yansıtmaktadır. Toplam 32 sorudan oluşan bu formda ilk 19 soru olumlu; son 13 soru ise olumsuz ifadelerden oluşmaktadır (Tablo 3). Formun ilk 19 olumlu ifadesinde "evet" yanıtı, son 13 olumsuz ifadesinde ise "hayır" yanıtı için birer puan verilmiştir. DEIDF'den alınacak maksimum puan 32'dir. Yüksek puan, katılımcıların doğum sürecinde bakım ve destek aldıkları ebelerin iletişim becerilerine ilişkin algısının olumlu olduğunu göstermektedir.

WDEQ Ölçeği'nin B Versiyonu, Wijma ve arkadaşları tarafından (1998) geliştirilmiş, Uçar E. (2013) tarafından Türkçe'ye uyarlanmıştır (17). Ölçek korku, güven, yalnızlık hissi, mutluluk gibi duygu ve düşünceleri içeren toplam 33 sorudan oluşmaktadır. Her madde 1-6 arasında puan alan 6'I likert tiptedir: 1 "tamamen", 6 ise "hiç" şeklinde ifade edilmektedir. Ölçekte bulunan negatif yüklü sorular $(2,3,6,7,8,11,12,15,19,20,24,25,27,31)$ ölçümde uyum sağlamak amacı ile ters yönde çevrilerek hesaplanmıştır. Ölçekte minimum puan 33 iken, maksimum puan 198 'dir. Puanın yüksek olması kadınların yaşadığı doğum de- 
neyiminin olumsuz olduğunu göstermektedir. WDEQ-B puanları dört alt grupta değerlendirilmektedir: Düşük derecede doğum korkusu yaşayanlar (WDEQ-B puanı $\leq 37$ olanlar), orta derecede doğum korkusu yaşayanlar (WDEQ-B puanı 38-65 arasında olanlar), ağır derecede doğum korkusu yaşayan kadınlar (WDEQ-B puanı 66-84 arasında olanlar), klinik derecede doğum korkusu yaşayan kadınlardır (WDEQ-B puanı $\geq 85$ olanlar). Uçar'ın (2013) çalışmasında WDEQ-B Ölçeği'nin Cronbach Alfa değeri 0.88 olarak bulunmuştur (17). Bu araştırmada WDEQ-B Ölçeği'nin Cronbach Alfa değeri 0.84'tür.

Verilerin Analizi: Verilerin analizi için Statistical Package for the Social Sciences (SPSS for Windows 15.00) istatistik programı kullanılmıştır. Veriler sayı ve yüzde dağıımları ile ortalamalar üzerinden verilmiştir. Kadınların sosyo-demografik ve obstetrik özelliklerine ilişkin verilerin analizinde sayı, yüzde, ortalama, standart sapma kullanılmıştır. DEIDF puan ortalaması ile WDEQ-B puan ortalaması arasındaki ilişkiyi değerlendirmek için korelasyon analizi kullanılmıştır.

Etik İzinler:Manisa Celal Bayar Tıp Fakültesi Yerel Etik Kurulu'ndan 13.04.2016 tarih ve 20478486.145 numaralı kararla etik izin; araştırmanın yürütülmesi için İzmir Buca Kadın Doğum ve Çocuk Hastalıkları Hastanesi'nin bağlı olduğu Kuzey Bölgesi Türkiye Kamu Hastane Birliği Genel Sekreterliği'nden kurum izni alınmıştır. Veri toplama aracı olarak kullanılan WDEQ-B Ölçeği'nin Türkçe'ye uyarlanmasını yapan Uçar'dan e-mail yoluyla izin alınmıştır. Çalışmaya katılmayı kabul eden ve çalışmaya katılma kriterlerine uygun kadınlara araştırmanın amacı ve içeriği ile ilgili bilgi verilip, "Hasta Bilgilendirilmiş Gönüllü Olur Formu" okuyup/okutularak sözlü ve yazılı onamları alınmıştır. Araştırma, Helsinki Deklarasyonu Prensipleri'ne uygun olarak yürütülmüştür.

\section{BULGULAR}

Normal doğum yapmış kadınların yaş ortalaması 26,72 $\pm 5,05$ olup çoğu ilkokul $(\% 30,3)$ mezunu ve ev hanımıdır $(\% 90,7)$; kadınların \%68,0'ı gelir durumunun gidere eşit olduğunu ifade etmiştir. Kadınların doğum sayı ortalaması $2,08 \pm 1,06$ 'dır. Son gebeliğinin planlı olduğunu ifade edenlerin oranı $\% 68,6$ 'dır. Kadınların \%43,9'una doğumda indüksiyon verilmiş ve $\% 78,2$ 'sine epizyotomi uygulanmıştır. Doğum eylemi süresince ortalama doğum salonunda kalma süreleri 7 saat 19 dakikadır. Doğum eyleminde takip eden ebe tarafından yaptırılan doğumun oranı $\% 88,7$; hekim ve doğumu takip eden ebenin birlikte yaptırdığı doğumların oranı \%11,3'tür (Tablo 1).
Tablo 1. Kadınların Sosyo-Demografik ve Obstetrik Özellikleri $n=353$

Yaş

\begin{tabular}{|l|c|c|}
\hline 26 Yaş ve Altt & 205 & 58,1 \\
$27-34$ Yaş & 117 & 33,1 \\
35 Yaş ve Üstü & 31 & 8,8 \\
\hline Eğitim
\end{tabular}

Okur-Yazar değil

36

10,2

Okur-Yazar

17

4,8

ilkokul

Ortaokul

107

30,3

Lise

Üniversite

Meslek

Ev Hanımı

Çalışan

$$
87
$$

24,6

Gelir Durumu

Gelir Giderden Az

Gelir Gider Eşit

Gelir Giderden Fazla

Doğum Sayısı

Bir

İki

Ü

Üç ve üzeri

Gebeliğin Planlı Olma Durumu

Planlı Olanlar

Planlı Olmayanlar

İndüksiyon Uygulanma

Durumu

İndüksiyon Uygulananlar

Indüksiyon

Uygulanmayanlar

Epizyotomi Uygulanma

Durumu

Epizyotomi Uygulananlar

Epizyotomi Uygulanmayanlar

Doğum Salonunda Kal-

ma Süresinin Ortalaması
23,5

6,5

83

23

320

90,7

33

9,3

24,9

68,0

7,1

36,0

32,6

31,4

111

-

2

242

68,6

111

31,4

43,9

56,1

198

78,2

21,8

7 saat 19 
Kadınların WDEQ-B Ölçeği puan ortalaması 89,9 olup en düşük değer 40 , en yüksek değer 165 bulunmuştur. Doğum eyleminde yaşanılan korku düzeyleri incelendiğinde; kadınların \%15,6'sı orta düzeyde, $\% 30,3$ 'ü ağır düzeyde, $\% 54,1$ 'nin klinik düzeyde doğum korkusu yaşadığı bulunmuştur (Tablo 2).

Tablo 2. Wijma Doğum Beklentisi / Deneyimi Ölçeği'ne Göre Kadınların Doğum Korku Düzeylerinin Dağılımı

\begin{tabular}{|c|c|c|}
\hline WDEQ B Ölçeği Alt Boyutları & Sayı & Yüzde \\
\hline Düşük (37ve ) & 0 & 0 \\
\hline Orta (38-65) & 55 & 15,6 \\
\hline Ağır (66-84) & 107 & 30,3 \\
\hline $\begin{array}{l}\text { Klinik Düzeyde Problemli } \\
\text { (85ve } \uparrow)\end{array}$ & 191 & 54,1 \\
\hline Toplam & 353 & 100,0 \\
\hline $\begin{array}{l}\text { WDEQ B Ölçeği Toplam Puan } \\
\text { Ortalaması }\end{array}$ & $\begin{array}{c}\text { Mean }=89,95 \pm 23,08 \\
(\text { Min=40, Max }= \\
165)\end{array}$ & \\
\hline
\end{tabular}

Kadınların sosyo-demografik ve obstetrik özelliklerine ile WDEQ-B Ölçeği'nin alt grupları arasındaki ilişki incelendiğinde; yaş, eğitim, meslek, gelir durumu, doğum sayısı, gebeliğin planlı olma durumu, indiksüyon ve epizyotomi uygulanma durumu, doğumu yaptıran kişi değişkenleri ile arasında istatistiksel olarak anlamlı fark bulunamamıştır $(p>0,05)$. Doğum salonunda kalma süresi ve doğum eyleminde ebelerle iletişim algısının WDEQ-B Ölçeği alt grupları arasında istatistiksel olarak anlamlı ilişki bulunmuştur $(p<0,05)$ (Tablo 3).

Tablo 3. Kadınların Sosyo-Demografik ve Obstetrik Özelliklerine Göre WDEQ-B Ölçeği Korku Düzeyi Puanları

\begin{tabular}{|c|c|c|c|c|c|c|c|c|}
\hline \multirow{3}{*}{$\begin{array}{l}\text { Sosyo-Demog- } \\
\text { rafik ve } \\
\text { Obstetrik Özel- } \\
\text { likler }\end{array}$} & & \multicolumn{7}{|c|}{ WDEQ-B Puanları } \\
\hline & \multicolumn{2}{|l|}{$\begin{array}{c}\text { Orta } \\
\text { Düzeyde Korku } \\
(38-65 \text { puan })\end{array}$} & \multicolumn{2}{|c|}{$\begin{array}{c}\text { Ağır } \\
\text { Düzeyde } \\
\text { Korku } \\
\text { (66-84 puan) }\end{array}$} & \multicolumn{2}{|c|}{$\begin{array}{c}\text { Klinik } \\
\text { Düzeyde } \\
\text { Korku }\end{array}$} & \multirow[t]{2}{*}{$\mathrm{x}^{2} / \mathbf{p}$} & \\
\hline & Sayı & $\begin{array}{c}\text { Yüz- } \\
\text { de }\end{array}$ & Sayı & $\begin{array}{c}\text { Yüz- } \\
\text { de }\end{array}$ & Sayı & $\begin{array}{c}\text { Yüz- } \\
\text { de }\end{array}$ & & \\
\hline \multirow[t]{3}{*}{ Yaş } & \multicolumn{2}{|l|}{$\begin{array}{r}26 \text { Yaş ve } \downarrow(\% 58,1) \\
33 \\
\end{array}$} & 16,1 & 64 & 31,2 & 108 & 52,7 & \multirow{3}{*}{$6,9 / 0,14$} \\
\hline & 27-34 Yaş $(\% 33,1)$ & 13 & 11,1 & 34 & 29,1 & 70 & 59,8 & \\
\hline & 35 Yaş $\uparrow(\% 8,8)$ & 9 & 29,0 & 9 & 29,0 & 13 & 41,9 & \\
\hline \multirow{6}{*}{ Eğitim } & Okur-Yazar Değil $(\% 10,2)$ & 7 & 19,4 & 12 & 33,3 & 17 & 47,2 & \multirow{6}{*}{$4,0 / 0,94$} \\
\hline & Okur-Yazar $(\% 4,8)$ & 2 & 11,8 & 6 & 35,3 & 9 & 52,9 & \\
\hline & \begin{tabular}{|l|} 
İlkokul $(\% 30,3)$ \\
\end{tabular} & 19 & 17,8 & 31 & 29,0 & 57 & 53,3 & \\
\hline & Ortaokul $(\% 24,6)$ & 11 & 12,6 & 28 & 32,2 & 48 & 55,2 & \\
\hline & Lise $(\% 23,5)$ & 12 & 14,5 & 26 & 31,3 & 45 & 54,2 & \\
\hline & Üniversite $(\% 6,5)$ & 4 & 17,4 & 4 & 17,4 & 15 & 65,2 & \\
\hline \multirow{2}{*}{ Meslek } & Ev Hanımı $(\% 90,7)$ & 51 & 15,9 & 100 & 31,3 & 169 & 52,8 & \multirow{2}{*}{$2,3 / 0,31$} \\
\hline & Çalışan $(\% 9,3)$ & 4 & 12,1 & 7 & 21,2 & 22 & 66,7 & \\
\hline \multirow{3}{*}{ Gelir Durumu } & \begin{tabular}{|l} 
Gelir Giderden Az $(\% 24,9)$ \\
\end{tabular} & 10 & 11,4 & 31 & 35,2 & 47 & 53,4 & \multirow{3}{*}{$5,4 / 0,24$} \\
\hline & Gelir Gidere Eşit $(\% 68,0)$ & 42 & 17,5 & 65 & 27,1 & 133 & 55,4 & \\
\hline & \begin{tabular}{|l|} 
Gelir Giderden Fazla $(\% 7,1)$ \\
\end{tabular} & 3 & 12,0 & 11 & 44,0 & 11 & 44,0 & \\
\hline \multirow[t]{3}{*}{ Doğum Sayısı } & Bir $(\% 36,0)$ & 12 & 9,4 & 41 & 32,3 & 74 & 58, & \multirow{3}{*}{$6,4 / 0,17$} \\
\hline & İki $(\% 32,6)$ & 24 & 21,1 & 33 & 28,9 & 57 & 50,0 & \\
\hline & Üç ve üzeri $(\% 31,4)$ & 19 & 17,0 & 33 & 29,5 & 60 & 53,6 & \\
\hline \multirow{2}{*}{$\begin{array}{l}\text { Gebeliğin Planlı } \\
\text { Olma Durumu }\end{array}$} & \begin{tabular}{|l|l|} 
Planlı Olanlar $(\% 68,6)$ \\
\end{tabular} & 43 & 17,8 & 77 & 31,8 & 122 & 50,4 & \multirow{2}{*}{$4,8 / 0,08$} \\
\hline & \begin{tabular}{|l|} 
Planlı Olmayanlar $(\% 31,4)$ \\
\end{tabular} & 12 & 10,8 & 30 & 27,0 & 69 & 62,2 & \\
\hline \multirow{2}{*}{ İndüksiyon } & Uygulananlar $(\% 43,9)$ & 23 & 14,8 & 49 & 31,6 & 83 & 53,5 & \multirow{2}{*}{$0,2 / 0,87$} \\
\hline & Uygulanmayanlar $(\% 56,1)$ & 32 & 16,2 & 58 & 29,3 & 108 & 54,5 & \\
\hline \multirow{2}{*}{ Epizyotomi } & \begin{tabular}{|l|} 
Uygulananlar $(\% 78,2)$ \\
\end{tabular} & 39 & 14,1 & 85 & 30,8 & 152 & 55,1 & \multirow{2}{*}{$2,0 / 0,36$} \\
\hline & Uygulanmayanlar $(\% 21,8)$ & 16 & 20,8 & 22 & 28,6 & 39 & 50,6 & \\
\hline
\end{tabular}

\begin{tabular}{|c|c|c|c|c|c|c|c|c|}
\hline \multirow{2}{*}{$\begin{array}{l}\text { Doğum Yaptı- } \\
\text { ran Kişi }\end{array}$} & Takip Eden Ebe $(\% 88,7)$ & 49 & 15,7 & 97 & 31,0 & 167 & 53,4 & \multirow[b]{2}{*}{$0,7 / 0,69$} \\
\hline & 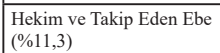 & 6 & 15,0 & 10 & 25,0 & 24 & 60,0 & \\
\hline \multirow{2}{*}{$\begin{array}{l}\text { Doğum Salo- } \\
\text { nunda Kalma } \\
\text { Süresi }\end{array}$} & 7 saat $18 \mathrm{dk}$. ve $\downarrow(\% 65,4)$ & 43 & 18,6 & 74 & 32,0 & 114 & 49,4 & \multirow[b]{2}{*}{$7,4 / 0,02$} \\
\hline & 7 saat $19 \mathrm{dk}$. ve $\uparrow(\% 34,6)$ & 12 & 9,8 & 33 & 27,0 & 77 & 63,1 & \\
\hline \multirow{2}{*}{$\begin{array}{l}\text { DEIDF } \\
(\mathrm{Or} t \pm \mathrm{Ss}= \\
25,03 \pm 6,5)\end{array}$} & $25,03 \downarrow$ & 10 & 7,5 & 25 & 18,7 & 99 & 73,9 & \multirow[b]{2}{*}{$34,4 / 0,00$} \\
\hline & $25,04 \uparrow$ & 45 & 20,5 & 82 & 37,4 & 92 & 42,0 & \\
\hline
\end{tabular}

Katıımcının DEIDF'in ilk 19 maddesine "evet", son 13 maddesine ise "hayır" cevabını vermesi, kendisine bakım veren ebenin iletişim becerilerini olumlu algıladığı şeklinde yorumlanmıştır. DEIDF'e verilen yanıtlarda katılımcıların \%23,3'ü ebelerinin kendisini tanıttığını, \%84,4'ü ebelerin yüz yüze iletişim kurduğunu ve dinlediğini, \%66,9'u ebelerin kendilerine isimleriyle hitap ettiğini, \%78,2'si ebelerin doğumda kendileriyle yeterince ilgilendiğini belirtmiş̧tir. Kadınların \%73,7'si tekrar doğum yapsa yine aynı ebenin yanında olmasını istediğini belirtmiştir. Katılımcıların en sık karşılaştıkları olumsuz davranışlar arasında; ebenin akıl vermesi $(\% 38,2)$, klişe sözlerle teselli etmesi $(\% 31,2)$ ve tersleme $(\% 22,9)$ ilk üç sırada gelmektedir (Tablo 4).

Tablo 4: Kadınların, Doğum Eyleminde Ebelerle İletişim Algısını Değerlendirme Formu Sorularına Verdikleri Yanıtların Dağııımı

\begin{tabular}{|c|c|c|c|c|c|}
\hline & \multirow[t]{2}{*}{ Ebelerin İletişim Davranışları } & \multicolumn{2}{|c|}{ Evet } & \multicolumn{2}{|c|}{ Hayır } \\
\hline & & Sayı & Yüzde & Sayı & Yüzde \\
\hline 1 & Ebeniz size kendini tanıttı mı? & 82 & 23,2 & 271 & 76,8 \\
\hline 2 & Ebeniz size isminizi sordu mu? & 288 & 81,6 & 65 & 18,4 \\
\hline 3 & Size isminizle hitap etti mi? & 236 & 66,9 & 117 & 33,1 \\
\hline 4 & Sizinle göz teması kurdu mu? & 298 & 84,4 & 55 & 15,6 \\
\hline 5 & $\begin{array}{l}\text { Ebeniz doğum süreci hakkında size yeterli bilgi verdi } \\
\text { mi? }\end{array}$ & 251 & 71,1 & 102 & 28,9 \\
\hline 6 & Ebeniz güler yüzlü müydü? & 265 & 75,1 & 88 & 24,9 \\
\hline 7 & Ebenizin konuşmaları anlaşı1ır mıydı? & 336 & 95,2 & 17 & 4,8 \\
\hline 8 & Duygularınızı ifade etmenize izin verdi mi? & 272 & 77,1 & 81 & 22,9 \\
\hline 9 & Sizinle konuşurken ses tonu uygun muydu? & 297 & 84,1 & 56 & 15,9 \\
\hline 10 & $\begin{array}{l}\text { Ebe soru sorduğunda, cevap vermeniz için yeteri kadar } \\
\text { zaman verdi mi? }\end{array}$ & 299 & 84,7 & 54 & 15,3 \\
\hline 11 & Sizin ona soru sormanıza izin verdi mi? & 292 & 82,7 & 61 & 17,3 \\
\hline 12 & Sizi dinledi mi? & 298 & 84,4 & 55 & 15,6 \\
\hline 13 & Sorularınıza cevap verdi mi? & 293 & 83,0 & 60 & 17,0 \\
\hline 14 & İhtiyaçlarınızı / sorunlarınızı giderdi mi? & 272 & 77,1 & 81 & 22,9 \\
\hline 15 & $\begin{array}{l}\text { Doğum sürecinde yapmak istediğiniz özel uygulamala- } \\
\text { ra sayg1 gösterdi mi? }\end{array}$ & 165 & 46,7 & 188 & 53,3 \\
\hline 16 & $\begin{array}{l}\text { Ebe sancılarla baş etmenize yardımcı olmak için size } \\
\text { yeterince zaman ayırdı mı? }\end{array}$ & 260 & 73,7 & 93 & 26,3 \\
\hline 17 & $\begin{array}{l}\text { Doğumda sizden istenilen davranışları yaptığınızda } \\
\text { ebeniz sizi destekledi mi? }\end{array}$ & 229 & 64,9 & 124 & 35,1 \\
\hline 18 & Ebe, doğumda sizinle yeteri kadar ilgilendi mi? & 276 & 78,2 & 77 & 21,8 \\
\hline 19 & $\begin{array}{l}\text { Tekrar doğum yapsanız yine aynı ebenin yanınızda } \\
\text { olmasını ister miydiniz? }\end{array}$ & 259 & 73,4 & 94 & 26,6 \\
\hline 20 & Ebeniz siz konuşurken sözünüzü kesti mi? & 55 & 15,6 & 298 & 84,4 \\
\hline 21 & Ebeniz siz konuşurken konuyu değiştirdi mi? & 32 & 9,1 & 321 & 90,9 \\
\hline 22 & Ebeniz sizi diğer gebelerle kıyasladı mı? & 35 & 9,9 & 318 & 90,1 \\
\hline 23 & Sizinle konuşurken sesini yükseltti mi? & 72 & 20,4 & 281 & 79,6 \\
\hline 24 & Sizi suçladı m1/yargıladı mı? & 48 & 13,6 & 305 & 86,4 \\
\hline 25 & Sizi eleştirdi mi? & 64 & 18,1 & 289 & 81,9 \\
\hline 26 & Size akıl verdi mi? & 135 & 38,2 & 218 & 61,8 \\
\hline 27 & Klişe sözlerle teselli etti mi? & 110 & 31,2 & 243 & 68,8 \\
\hline 28 & Sizi tersledi mi? & 81 & 22,9 & 272 & 77,1 \\
\hline 29 & VW22QAAHesap sorar tarzda konuştu mu? & 28 & 7,9 & 325 & 92,1 \\
\hline 30 & Size ihtiyacınız olmadığı halde öğüt verdi mi? & 43 & 12,2 & 310 & 87,8 \\
\hline 31 & Abartılı övgülerde bulundu mu? & 14 & 4,0 & 339 & 96,0 \\
\hline 32 & Sizin özel bilgilerinizi başkalarıyla paylaştı mı? & 4 & 1,1 & 349 & 98,9 \\
\hline
\end{tabular}

Kadınların DEIDF'den aldıkları puanların WDEQ-B Ölçeği puanlarına göre dağılımı incelendiğinde; iletişim algısı puanları arttıkça doğum deneyimi puanlarının düştüğü görülmüştür (Grafik 1). 
Grafik 1. Wijma Doğum Beklentisi /Deneyimi Ölçeği B Versiyonu (WDEQ-B) Puanı ile Ebelerle İletişim Algı (DEEIAD Formu) Puanı Arasındaki İlişki

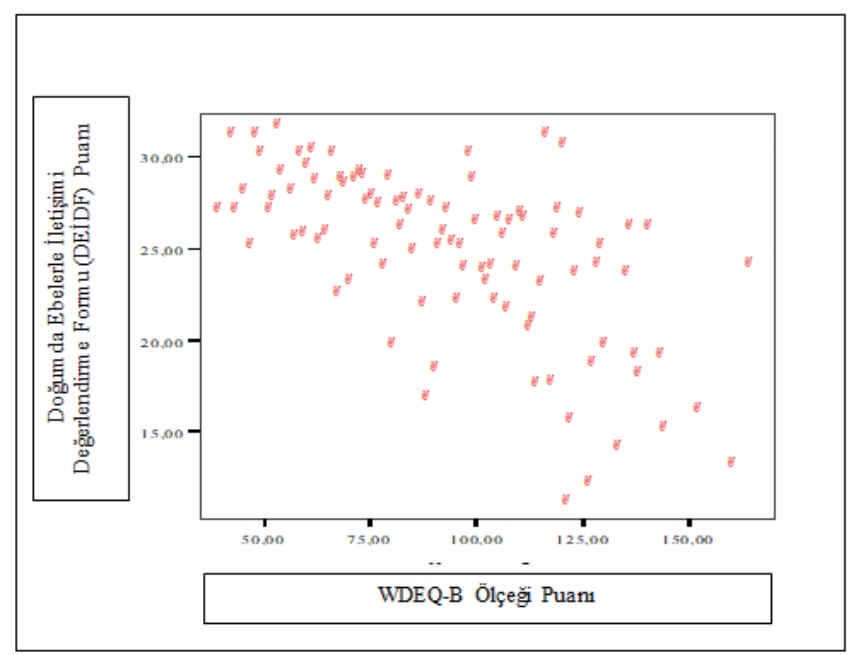

Ayrıca, kadınların doğum eyleminde ebelerin iletişim tarzına ilişkin algı puanı ile doğum deneyimine ilişkin puan arasındaki korelasyon analizinde; negatif yönde, orta düzeyde güçlü ve istatistiksel olarak anlamlı bir ilişki olduğu saptanmıştır ( $r=-, 36$; $\mathrm{p}=0.00$ ) (Tablo 5).

Tablo 5. Doğumda Ebelerle Illetişimi Değerlendirme Formu (DEIDF) ile Wijma Doğum Beklentisi /Deneyimi Ölçeği B Versiyonu (WDEQ-B) Ölçek Puanı Arasındaki Korelasyon Değeri

\begin{tabular}{|l|l|}
\hline Korelasyon kat sayısı (r) & P \\
\hline,- 36 & $\mathbf{0 , 0 0}$ \\
\hline
\end{tabular}

\section{TARTIŞMA}

Doğum eylemi süresince kadının fiziksel, psikolojik ve çevresel nedenlerle yaşadıklarının tümü doğum deneyimini oluşturur. Bireysel özellikler (gebeliğin istenme durumu, eş uyumu, sosyal destek, doğum hakkında bilgi, düşünce, inanç ve korkular), doğum esnasında yapılan müdahaleler, doğumda stres yaratan durumlar (kendi ya da bebeğin sağlığı ile ilgili), bakımın kalitesi (bakım verenlerin yeterli destek vermesi ve iletişimi) gibi faktörler doğum deneyimini etkilemektedir $(1-5,7,18)$. Bu çalışmada, doğumda bakım kalitesi için hayati önem taşıyan ebelerin kadınlarla kurduğu iletişimin doğum deneyimi ile ilişkisi incelenmiştir. Kadınların doğum deneyimlerinin değerlendirildiği WDEQ-B Ölçeği'nden alınacak minimum puan değeri 33, maksimum değer ise 198'dir (17). Çalışmaya katılan kadınların WDEQ-B Ölçeği'nden aldıkları toplam puan ortalaması $89,95 \pm 23,08$ 'dir. Ölçek toplam puanının orta değerin üzerinde olması katılımcıların doğum deneyimin olumsuz olduğunu göstermektedir. Kadınların doğum korkusu düzeyini ifade eden ölçek alt boyutları incelendiğinde çoğunun $(\% 54,1)$ klinik düzeyde doğum korkusu yaşadığı anlaşımaktadır. WDEQ-B Ö/çeği puan ortalamaları ile DEIDF puan ortalamaları arasındaki ilişkinin gösterildiği Grafik 1'de, kadınların ebenin iletişim kurma tarzına ilişkin algısını ifade eden puan artıkça doğum deneyimi puanının düştüğü görülmektedir. Yapılan korelasyon analizinde de iletişim algısı puanı ile WDEQ-B Ölçeği puanı arasında negatif yönde, orta düzeyde güçlü ve istatistiksel olarak anlamlı bir ilişki (Tablo 5) $(r=-, 36 ; p<0.05)$ olduğu saptanmıştır. Doğum süresince ebelerin kendileri ile olumlu iletişim kurduğu algısına sahip kadınların doğum deneyimlerinin de olumlu olduğu görülmüştür. Bulgular, doğum eyleminde sağlık çalışanlarının iletişim tarzının doğum deneyimini etkilediğini vurgulayan araştırma bulgularını $(1,5,7,11-13,15,19,20)$ destekler niteliktedir.

Doğum deneyimini ve korkusunu, bakım veren ebenin kurduğu iletişim dışında doğumda yapılan müdahaleler veya yaşanan stres düzeyi gibi farkı faktörler de etkileyebilmektedir $(2,20-22)$. Bu çalışmada doğum sürecinde yapılan müdahaleler (epizyotomi, indüksiyon), sosyo-demografik özellikler (yaş, eğitim, meslek, gelir durumu) ve obstetrik özellikler (doğum sayısı, gebeliğin planlı olma durumu) ile WDEQ-B puanları arasında istatistiksel olarak anlamlı bir ilişki bulunamamıştır $(p<0,05)$. Preis ve arkadaşlarının yaptığı çalışmada da sosyo-demografik ve obstetrik özellikler ile doğum memnuniyeti arasında istatistiksel olarak anlamlı ilişki bulunmamıştır. Fakat, doğumda uygulanan tıbbi müdahaleler (indüksiyon, epidural analjezi, sezaryen vb.) kadınların doğum korkusu arttırarak olumsuz doğum deneyimi yaşamalarına neden olmuştur (18). Sosyo-demografik ve obstetrik nedenlerin doğum korkusuyla ilişkisinin incelendiği Çiçek ve Mete'ye ait derleme çalışmasında, araştırma bulgularının farklılık gösterdiği vurgulanmaktadır. Alan yazınında söz konusu değişkenlerin ilişkili olduğunu gösteren çalışmaların yanı sıra bir ilişki olmadığına dair bulgular elde edilmiş çalışmalar da bulunmaktadır (20). Sigurdardottir ve arkadaşlarının çalışmasında, indüksiyon uygulanan kadınların spontan doğum yapan kadınlardan daha olumsuz doğum deneyimi yaşadıkları belirlenmiştir (3). İşbir ve Serçekuş'un çaış̧masında ise doğum eyleminde oksitosin kullanımının doğum korkusunu etkilemediği tespit edilmiştir (21). Bu araştırmanın bulguları incelendiğinde, doğum korkusunu etkileyen epizyotomi ve indüksiyon uygulanması ile WDEQ-B Ölçek puanları arasında anlamlı bir ilişki olmadığı görülmektedir $(p>0,05)$; diğer yandan epizyotomi ve indüksiyon müdahalelerinin uygulandığı kadınlarda klinik düzeyde korku yaşayanların oranının yüksek olması dikkat çekicidir. Doğum deneyiminin olumsuz algılanma$\mathrm{Sı}$, klinik düzeyde korku yaşanması ile ilişkili olabilir. Müdahaleli doğumlar kadınların doğum korkusunu arttırmakta ve olumsuz doğum deneyimi yaşanmasına neden olmaktadır.

Doğum stresini artıran durumlardan biri de travay sürecinin ve doğum salonunda kalma süresinin uzamasıdır. Martin ve Fleming'in çalışmasında, travay süresinin uzamasının anksiyeteyi ve bireysel kontrolün azalmasına bağlı olarak doğumda memnuniyetsizliği arttırdığı belirtilmiştir (2). Bu araştırmada, doğum salonunda kalma süresi ile doğum beklentisi/deneyimini ifade eden WDEQ-B Ölçek puanı arasında anlamlı ilişki olduğu görülmüştür $(p>0,05)$. Doğum salonunda kalma süresinin uzaması (7 saat $19 \mathrm{dk}$. ve üzeri olanlarda) klinik düzeyde doğum korkusu yaşama oranını artırmıştır. Çalışma sonuçları, travay süresinin uzamasının doğum deneyimini negatif yönde etkilediğini göstermektedir. Travay süresinin uzamasının kadının endişe ve anksiyetesini, doğumda yapılan girişimleri arttırabileceği; bu durumun doğum korkusu düzeyi ve doğum deneyimi üzerinde olumsuz yönde etkisi olacağı düşünülebilir.

DEIDF puan ortalaması $25,03 \pm 6,5$ olup DEIDF puan ortalamaları ile WDEQ-B Ölçek puanları arasında istatistiksel olarak 
anlamlı bir ilişki olduğu bulunmuştur $(p<0,05)$ (Tablo 3). Doğum eyleminde ebelerin iletişim biçimine ilişkin algı puanı düştükçe klinik düzeyde yaşanan doğum korkusu artmış ve doğum deneyimi olumsuz yönde etkilenmiştir. Kadınların doğumda kendilerinin rahat ve güvende olduğunu hissetmesi, endişe ve stresi aşmalarını ve yapılan müdahalelerin gerekliliğine inanmalarını sağlamaktadır (1). Ebelerin doğum eyleminde olumlu iletişim davranışı sergilemesi, kadınların kaygı düzeyini ve doğum korkusunu azaltmaktadır.

Kadınların doğum eyleminde algıladıkları olumlu iletişim tarzlarının başında, ebelerin konuşmasının anlaşılır olması (\%95,2) ve soru sorduktan sonra konuşmaları için yeteri kadar zaman vermesi $(\% 84,7)$ gelmektedir. Gebelerin ebelerden empatik beklentilerinin ve karşılanma durumunun incelendiği Çankaya ve arkadaşlarına ait çalışmada da kadınlar, ebelerin çoğunun (\%73) açıklayıcı ve güzel konuştuğunu belirtmiştir (12). Ebelerin açıklayıcı ve anlaşıı konuşmasının sözel iletişimin niteliği açısından önemli olduğu, kadınların çoğu tarafından olumlu algılandığı görülmektedir.

Doğum eyleminde ebenin sakin, olumlu, güven veren bir yaklaşıma sahip olması, bilgi vermesi, uygun geri bildirimde bulunması, kadınların kendilerine duydukları güveni artırmaktadır $(1,2,9,16)$. Kızılkaya'nın çalışmasında kadınların doğumda en yararlı buldukları ebelik davranışları; bakım verirken sakin ve kendinden emin görünme, saygılı davranma, birey olarak değerli ve güvende hissettirmedir (13). Bu araştırmada ebenin göz teması kurması ve dinlemesi $(\% 84,4)$, ses tonunun uygun olması $(\% 84,1)$ ve sorulan sorulara yanıt vermesi $(\% 83,0)$, güler yüzlü olması $(\% 75,1)$, bilgi vermesi $(\% 71,1)$, yeterince ilgilenmesi $(\% 78,2)$, yardım etmesi $(\% 77,1)$, isim ile hitap etmesi $(\% 66,9)$ katıımcılar tarafından yüksek oranda olumlu biçimde algılanmıştır. Kadınların çoğu $(\% 73,4)$ tekrar doğum yapacak olsa yine aynı ebenin yanında olmasını istediğini belirtmiştir (Tablo 4). Bulgular kadınların doğum eyleminde sağlık çalışanlarından saygı görme, değer verildiğini ve güvende olduğunu hissetme, bilgilendirilme ihtiyacı intiyacı içinde olduklarını göstermektedir. Kadınların çoğunun ebelerin iletişim davranışlarını olumlu algılamış olmasından yola çıkılarak, doğum eyleminde intiyaç ve beklentilerinin karşılandığı sonucuna varılabilir.

Üst ve Pasinlioğlu'nun primipar ve multipar gebelerde doğum ve doğum sonu döneme ilişkin endişeleri incelediği araştırmasında, doğum sırasında sağlık personelinin davranışının en yüksek endişeyi yarattığı saptanmıştır (4). Çankaya ve arkadaşlarının yaptığı araştırmada ise katııımcıların tamamına yakınının $(\% 98,5)$ doğumda ebelerin saygılı olmasını beklediği, ancak bu beklentinin doğumda yeterince karşılanmadığı belirtilmiştir (12). Çalışmaya katılan kadınların \%53,3'ü doğum sürecinde yapmak istediği özel uygulamalara saygı gösterilmediğini ifade etmiştir. Araştırma sonuçları, sağlık bakımı hizmeti alan bireylerin kendilerine saygı gösterilmesi ile ilgili beklenti ve endişelerinin olduğunu ve bu beklentilerinin yeterince karşılanmadığını göstermektedir.

Hasta ya da sağ|ıkı bireye değer verme, saygılı olma ve bilgilendirme gibi olumlu iletişim davranışlarının farkında olunması, sağık çalışanlarının görev ve sorumlulukların yerine getirilmesi sağlık bakım kalitesini ve memnuniyeti arttırmak için önemlidir $(6,10,22,23)$. Ebelerin gebelerle ilk karşılaşma aşamasından itibaren iletişimi nasıl başlatıp sürdürdüğü hem doğum sürecini hem de doğum sonrası dönemini etkilemektedir $(6,11,23)$. KatıIımcıların ifadelerinden etkili iletişimde önemli bir yeri olan "kendini tanıtma"nın büyük oranda inmal edildiği, ebelerin kadınların çoğuna $(\% 76,8)$ kendilerini tanıtmadığı anlaşılmıştır. Çankaya ve arkadaşlarının çalışmasında, karşılaşma ve tanışma aşamasında "el sıkışma"nın en az rastlanan iletişim davranışı olduğu belirlenmiştir. Bu davranışı, "yol gösterici olma" yaklaşımı, "anlayışılı।k", "karşısındakine değer verme", "karşısındakinin yüzüne bakarak konuşma" izlemektedir (12). Bu araştırmanın bulguları da ilk karşılaşma aşamasında iletişim için oldukça önemli olan tanışmanın inmal edildiğini göstermektedir. Kadınların algıladıkları ebelerin diğer olumsuz iletişim davranışları ise akıl vermesi $(\% 38,2)$, klişe sözlerle teselli etmesi $(\% 31,2)$, terslemesi $(\% 22,9)$, konuşurken sesini yükseltmesi $(\% 20,4)$, eleştirmesidir $(\% 18,1)$. Çankaya ve arkadaşlarının çalışmasında, doğum yapan kadınların \%7'sinin ilgisizlik, \%6,5'inin değer verilmeme, $\% 5,5^{\prime}$ 'inin azarlanma, $\% 3,5^{\prime}$ 'inin kaba davranılması ve \%3'ünün ebenin güler yüzlü olmaması gibi olumsuz iletişim davranışlarına maruz kaldığı belirtilmiş̧ir (12). Bu araştırma bulgularına göre ebelerin algılanan olumsuz iletişim davranışları olumlu iletişim davranışlarından daha düşük orandadır. Fakat kadınların olumlu doğum deneyimi yaşaması, doğum korkusunun azaltıması ve ebelik bakım kalitesinin arttırıması açısından bulgular, ebelerin etkili ve olumlu iletişim becerileri kazanması gerekliliğini vurgulamaktadır.

\section{SONUÇ}

Inssani haklar bağlamında olumlu bir doğum deneyimi yaşamak, doğumda saygılı, güven verici ve destekleyici sağlık bakım hizmeti almak tüm kadınların hakkıdır. Araştırmanın bulguları, bu hakkın ebelerin iletişim becerileri ve davranışları ile ilişkili olduğunu göstermektedir. Doğum eyleminde ebelerin iletişim davranışlarını olumlu algılayan kadınların, doğum deneyiminin de olumlu olduğu belirlenmiştir. Normal doğum yaptırma yetkinliğine sahip ebelerin, anne, bebek sağlığının korunması ve geliştirilmesi, kadınların olumlu doğum deneyimi yaşaması açısından mesleki ve asli önemlerinin farkında olması gerekir. Ebelerin iletişim becerileri ile kadınların doğum deneyimi arasındaki ilişki, bu alanda daha fazla çalışma yapılması gerektiğini göstermektedir. Bu nedenle ebelerin iletişim becerilerini geliştirmeyi amaçlayan hizmet içi eğitim programları hazırlanmalı, ebelik lisans programlarının müfredatı kişilerarası iletişim becerilerinin geliştirilmesi açısından zenginleştirilmeli ve bu alanda farkındaıı̆̆ın artıııımasına yönelik çalışmalar yapıımalıdır.

Teşekkür

Araştırmaya katılmayı kabul ederek destek veren tüm kadınlara teşekkür ediyoruz.

\section{KAYNAKLAR}

1. Dahlberg U, Persen J, Skogas, AK, Selboe S T, Marit Torvik H Al. How can midwives promote a normal birth and a positive birth experience? The experience of first-time Norwegian mothers. Sex Reprod. 2016;7:2-7.

2. Martin $\mathrm{CH}$, Fleming V. The birth satisfaction scale. Int J Health Care Qual Assur. 2011;24(2):124-35. 
3. Sigurdardottir VL, Gamblec J, Gudmundsdottir B, Kristjansdottir H, Sveinsdottir H, Gottfredsdottira $H$. The predictive role of support in the birth experience: A longitudinal cohort study. Women and Birth. 2017;30:450-459.

4. Üst Z, Pasinlioğlu T. Primipar ve multipar gebelerde doğum ve postpartum döneme ilişkin endişelerin belirlenmesi. Sağık Bilim ve Meslekleri Dergisi. 2015;2(3):306-17.

5. Yilmaz E, Nazik F. The Correlation Between Perception of Birth And Nursing Care Levels of Mothers. Tip Dergisi The Journal of Gynecology-Obstetrics and Neonatology Jinekoloji-Obstetrik ve Neonatoloji Tıp Dergisi. 2018;15(2):52-55.

6. Dahlberg U, Aune I. The woman's birth experience-The effect of interpersonal relationships and continuity of care. Midwifery. 2013;29:407-15.

7. Pantoja L, Weeks FH, Ortiz J, Cavada G, Foster J, Binfa L. Dimensions of childbirth care associated with maternal satisfaction among low-risk Chilean women. Health Care Women Int . 2020;41(1):89-100.

8. Boz İ, Mehtap A, Uçan H, Duman F, Göksu M, Çoşkun G, et al. Gebelerin Doğum Eyleminde Algıladıkları Destekleyici Bakım ile Doğum Algıları Arasındaki İlişkinin Belirlenmesi. Jinekoloji - Obstet ve Neonatoloji Tip Derg. 2019;16(4):187-90.

9. Chang YS, Coxon K, Portela AG, Furuta M, Bick D. Interventions to support effective communication between maternity care staff and women in labour: A mixed-methods systematic review. Midwifery. 2018;59:4-16.

10. Hodnett ED, Gates S, Hofmeyr GJ, Sakala C. Continuous support for women during childbirth. Hodnett ED, editor. Vol. 2013, Cochrane Database of Systematic Reviews. Chichester, UK: John Wiley \& Sons Ltd; 2013.

11. Ildan Calim S, Saruhan A. The Effect of interpersonal communication training given according to the Travelbee Theory on midwives' communications skills and mothers' birth satisfaction. Life Science. 2019;14(4):104-21.

12. Çankaya S, Ak A, Polat Y, Filiz F, Künduro F, Mızrak F, et al. Doğum için başvuran gebelerin empatik iletişim beklentilerinin ebeler tarafından karşılanma durumu. Genel Tıp Dergisi: 2014;24: 7-14.

13. Kızılkaya N. Kadınların doğum eylemindeki destekleyici hemşirelik davranışlarına yönelik görüşleri. Perinatoloji Dergisi. 1997(5): 113-116.
14. Pınar G, Pınar T. Yeni Doğum yapmış kadınların empatik iletişim beklentilerinin ebe/hemşireler tarafından karşılanma durumu. Tıp Araştırmaları Dergisi. 2009:7(3):132-140.

15. Grigoryan R, Thompson ME, Crape B, Hekimian K. Explaining Women's High Satisfaction With Objectively Poor Quality Childbirth Services: Armenia as a Case Study. Health Care Women Int. 2015;36(1):121-34.

16. Dağlar G, Güler H. Ebelerin doğum anında annelere verdiği bakım hizmeti: Annelerin değerlendirmeleri ve beklentileri. Artemis, 2004;5(1): 42-47.

17. Uçar E, Kızılkaya Beji N. Wijma Doğum Beklentisi /Deneyimi Ölçeği B Versiyonu' nun Geçerlik Ve Güvenirlik Çalışması . Haliç Üniversitesi Sağlık Bilimleri Enstitüsü, Yüksek Lisans Tezi (Danışman: Prof. Dr. Nezihe KIZILKAYA BEJi). İstanbul, 2013.

18. Preis $H$, Lobel M, Benyamini Y. Between Expectancy and Experience: Testing a Model of Childbirth Satisfaction. Psychol Women Q. 2019 Mar 1;43(1):105-17.

19. Nilsson L, Thorsell T, HertfeltWahn E, Ekström A. Factors influencing positive birth experiences of first time mothers. Nursing Research and Practice. 2013(6):349124

20. Çiçek Ö, Mete S. Sık Karşılaşılan Bir Sorun: Doğum Korkusu. Dokuz Eylül Üniversitesi Hemşirelik Yüksekokulu Elektron Dergisi. 2015;8(4):263-8.

21. İsbir GG, Topcu B. Effects of Intrapartum Oxytocin Induction on the Labor Pain and Fear of Labor. J Educ Res Nurs. 2018;15(2):94-8.

22. Murphy $\mathrm{H}$, Strong J. Just another ordinary bad birth? A narrative analysis of first time mothers' traumatic birth experiences. Health Care Women Int. 2018;39(6):619-43.

23. Kitzinger $\mathrm{C}$, Kitzinger $\mathrm{S}$. Birth trauma: talking with women and the value of conversation analysis. $\mathrm{Br} \mathrm{J}$ Midwifery. 2007;15(5):256-64. 